\title{
Effects of government actions on safety and security perceptions of international students during COVID-19 pandemic in China
}

George N. Chidimbah Munthali ( $\sim$ huaitian07@outlook.com )

Yangtze University-School of Economics and Management, 1 Nanhuan Road, Jingzhou, Hubei, P.R.

China https://orcid.org/0000-0002-1513-7312

Wu Xuelian ( $\nabla$ wuxuelian@yangtzeu.edu.cn )

Yangtze University-School of Economics and Management, 1 Nanhuan Road, Jingzhou, Hubei, P.R.

China https://orcid.org/0000-0001-7409-1417

Shi Yu ( $\nabla 1921243432 @ q q . c o m)$

Yangtze University-School of Economics and Management, 1 Nanhuan Road, Jingzhou, Hubei, P.R. China

John Feston Kudzala ( $\nabla$ kudzalajohn@gmail.com )

Mzuzu Technical College PO Box 316 Mzuzu, Malawi

\section{Research Article}

Keywords: COVID-19, Safety, Security, International Students, government actions, Perceptions

Posted Date: January 25th, 2021

DOl: https://doi.org/10.21203/rs.3.rs-154307/v1

License: (9) This work is licensed under a Creative Commons Attribution 4.0 International License. Read Full License 


\section{Abstract}

Introduction: International students' safety and security matters as they are migrants and foreigners belonging to a special minority group of people that need to be protected each and every time in breach of which may have diplomatic and international endeavors. This study was aimed at finding the effects of government actions in regards to safety and security perceptions of international students in China during COVID-19 Pandemic.

Materials and methods: A cross- sectional design survey was conducted in March 2020 from 13 different universities in Hubei province of China. Data was collected through an online Microsoft questionnaire which was send to selected universities groups that were purposively and conveniently sampled. IBM SPSS version 24 software was used to analyses the data; Pearson correlational was performed at statistical significance put at* $p<0.05 ;{ }^{* *} \mathrm{p}<0.01$.

Results: 300 questionnaires were received out of 392, representing a response rate of $76.5 \%$, majority of the respondents were in age group of $20-3086 \%$, single $93 \%$, undergraduate $79 \%$, stayed 2 years above $61 \%$, belonging to Christianity $51.7 \%$ and Islam $37 \%$. Furthermore, there was a positive correlation between social distance measures and safety and security perceptions, but there was no correlation between information dissemination and safety and security perception, lastly, the results showed that students were materially supported with their respective authorities and that the political will was good.

Conclusion: The actions of the government especially through the social distance measures have proved to positively increase international students' safety and security perceptions. Further, authorities tried to facilitate material and social support to the students. We recommend authorities to continue putting the safety and security of international students at their heart as it is demonstrated in China.

\section{Introduction}

Coronavirus (COVID-19) which started end last year December 2019 in Wuhan China is still causing pervasive impacts in all the aspects of life in the whole world ${ }^{1-4}$, as many scientists are still in working on therapy that could prove successful ${ }^{5}$. Specifically COVID-19 is impacting negatively all areas of development i.e. agriculture ${ }^{6}$, transportation sector ${ }^{7}$, trade, health, education ${ }^{8}$ etc. The negative impacts of COVID-19 on education sector has been witnessed by many indicators like through the physical closure of academic institutions due to restrictions of public gatherings by social distance measures that are advised to be followed by the World Health Organisation (WHO) and other authorities with the aim of reducing the transmission of the virus ${ }^{1,9-11}$. The academic journey of students all over the world has been negatively affected with this pandemic, many countries have started exploring online platforms for learning as the most reliable option, while some countries especially developing economies, found it difficult to explore the online possibilities because of limited of resources leading to total closure of academic activities ${ }^{10}$. However, it is of utmost importance to examine the extent of the impacts of 
COVID-19 on the students that are studying in foreign countries as compared to those their counterparts who are studying at home countries.

\subsection{Students mobility and China boom for international students}

The number of foreign students globally has increased from 2 Million in 1998 to about 5.3 Million as at 2017, especially when the students are on stage of advancing in their academic levels with Australia, United States of America (USA), United Kingdom (UK), New Zealand and China being some of the most notable destination of these foreign students ${ }^{12,13}$ (See figure 1). Despite several debates on the definition of international students (IS) in literature, scholars and other international organisations have tried to differentiates these students by categorising them into three groups namely; degree-mobile students, foreign student, and international students. For the sake of this study, we adopted the international students definition which was agreed upon and was defined as: 'Students who have crossed a national or territorial border for the purpose of education and are now enrolled outside their country of origin'12,14 to refer to all the students that were subject and respondents of this study in China.

China is one of the country where recently has been recorded as a destination attraction of many international students which are close to 492,185 from 196 countries studying in more than 1,004 higher education institutions with an increasing enrolment rate of $15.04 \%$ per year as indicated by China on Ministry Of Education (MOE) statistical reports in 2019 ${ }^{15-17}$. The increase of foreign Students in China has been attributed through the Chinese government initiatives to make reforms and invest heavily in their educational system in order to accommodate foreign students and compete at international level ${ }^{18}$. Furthermore, many IS have been attracted to study in China through initiatives by the Chinese government by offering scholarships which representing $12.81 \%$ of the total population of the IS, these scholarships ranges from; Ministry of Commerce Scholarship (MOFCOM), Chinese Government Scholarship(CGC), Provincial-Based Scholarship(PBS), University-Based Scholarship (UBS), etc. with majority of them coming from countries that are in a relationships with China through One Belt One Road (OBOR), which have even fostered a strong relationship between China and the patterned countries in all areas of development ${ }^{19,20}$. Despite having these scholarships, the other group of foreign students are studying through self-sponsorship programs which form a large part of the population that is about $87.19 \%$ with Asia and Africa continent being the leading continents where these IS are from respectively

15. The majority of these self-sponsored students choose China because of many reasons some being affordability of living expenses, safety and security, affordable tuition fees and advancement of learning environment $16,17,21,22$.

\subsection{Safety and Security}

Generally, the safety and security of the foreigners has always been one of the main priorities to be addressed by those in authorities in many countries as it involves diplomatic endeavours ${ }^{23-25}$. Foreign 
students attain a special status of belonging to special social minority group which is supposed to be

protected by those in authorities in the host country ${ }^{26}$, as a result of the attainment of this special status, foreign students have special needs that need to be addressed regularly ${ }^{27}$. Therefore, with these facts, it is not surprising to know that safety and security factor are part of the main factors that contribute to the final decisions of IS regarding their study destination as demonstrated in the Pull-Push theory. This theory states that there are Push factors that push students to go outside their countries for further educations like lack or limited access to higher education in their home countries, ability to change their social economic life and that there are Pull factors that pull or attract IS to choose their destination like the conducive environment of the host country i.e. safety and security, political stability, the cost of tuition fees and living ${ }^{12,28}$. Despite having vast literature on IS safety and security in general $26,29,30$, there are limited previous studies on the aspect of government policies or actions especially during viral disease outbreaks like COVID-19 pandemic which has not only affected foreign students safety and security perceptions but also the entire world. Therefore, this study tries to fill this research gap which is currently existing in the literature ${ }^{31,32}$.

This study was aimed at examining the perceptions of IS on their safety and security in China during COVID-19 pandemic as a result of actions taken by the government. The findings of this study will be of high significant as it will provide a new insight of knowledge base to the policy makers or authorities on where to improve the standards of actions enforced. Secondly, the results will help all the potential foreign students who may be willing to study abroad to make sound decisions, and lastly, will supplement the existing literature on safety and security of foreign students in developing economies in the world.

\subsection{Statements of hypothesis}

This study was guided by these hypotheses:

i) $\left(\mathrm{H}_{0 \text { : ' }}\right.$ Government Social distances measures had a positive impact on IS safety and security perceptions'

$\left(\mathrm{H}_{1}\right.$ 'Government Social distances measures had a negative impact on IS safety and security perceptions"

ii) $\left(\mathrm{H}_{0}\right.$ : 'Government information dissention measures (actions) had a positive impact on IS safety and security perception'

( $\mathrm{H}_{1}$ 'Government Information dissention measures (actions) had a negative impact on IS safety and security perception',

\section{Materials And Methods}

\subsection{Research variables}


In coming up with research variables this study was guided by most of the literatures from criminology studies, as they are the ones associated with influence on safety and security issues, we opted to choose this way of thinking because literature indicates that IS belong to special minority group that are socially vulnerable by applying the vulnerability theory which has been used in many safety and security studies from all over the world ${ }^{33-35}$. Literature indicates that government policies, measures and actions are one of the major contributing factors that may influence safety and security of the country in general at a national level and of its citizen, furthermore, the policies may also influence foreigners safety and security perceptions in times of wars, epidemics and pandemics or any disasters ${ }^{24,36-38}$, to the extents that if well implemented and followed they may even reduce the spread of pandemics like of that of COVID-19 infectious disease ${ }^{38}$.

\subsubsection{Safety and security perception}

In this study, the first variable is perception or sense of safety and security of IS. Generally, from literature, these two concepts are defined as: Security; 'the state of being away from hazards caused by deliberate intention of human to cause harm. The source of hazard is posed by human deliberately ${ }^{39}$ '. Safety ; 'the state of being away from hazards caused by natural forces or human errors randomly, the source of hazard is formed by natural forces and/or human errors. ${ }^{39}$. Safety can also be defined as; 'to the physical, social, psychological and emotional conditions of being protected against danger, risks, and harm ${ }^{40}$. Safety and security can be further grouped into personal and property, as it is noted from the definitions, safety and security are broad concepts on their own, as such for the sake of this study we will only focus on personal aspects of it which may be affected by the actions of the government during the pandemic period, i.e. physical harm, economic harm and psychological harm aspects. In this study IS' safety and security perception were measured by questions that asked about satisfaction with personal safety and security in China in amidst of COVID-19 with NO representing 1 lower safety and security perception, or Yes representing 2 higher safety perception respectively and vice versa depending on the nature of the question being asked.

\subsubsection{Information dissemination}

Literature indicates that dissemination of information by those in authorities especially the local authorities in the host countries at an appropriate time have the impact of increasing knowledge level of the migrant's people which has a positive impact in perception of their safety in the host country 41,42 .

\subsubsection{Social distancing measures}

Literatures indicates that if implemented and followed properly lockdowns and other social distance measures may help to prevent the spread of infectious disease despite having disruptions of social economic activities and perceived both positively and negatively by people on safety and security 1,43-45.

Variables of information dissemination and social distance measures were measured by asking questions to the respondents which were in binary form coded as Yes $=1$ and $\mathrm{No}=0$ which was later 
converted to means scores for further analysis.

\subsubsection{Characteristics of people in the study}

The other variables of the study were (i) gender where the literatures indicates that male have higher safety perception as compared to female, (ii) age where old people have high safety perception than younger ones, (iii) education level where those with high education level have high safety perception than those with low education levels, (iv) length of stay, where those that have more stayed have higher safety perceptions as compared with those with no more experience, (v) marital status where the literature indicates that those that are married have higher safety perception as compared to those that are not married $34,41,46,47$, (vi) regional comparison, where the literature has indicated that even a location where people are located with an area, i.e. those that may be close to military base may feel high security than others, those that are located far from pandemics starts points may have higher security perception than others $30,41,48$. The measurement of these variables was as follows, gender in binary 1 and 2 representing male and female, age in number of years, education level in ranks of undergraduate and postgraduate, experience as length of stay based on years of stay in China, marital status as single, married or divorces, and lastly regional comparison of universities measured those universities in Wuhan and those that were outside Wuhan. These variables were coded using numbers 1 to 5 in excel sheet before importing into the SPSS for analysis.

\subsection{Study design and population}

This study used exploratory methodology which relied both on reviewing the literatures online on official Chinese Government website, peer reviewed published articles and published Chinese school notifications, furthermore this study used a cross sectional design survey which was conducted on the first week of May 2020 in 13 selected universities in Hubei China (Central China Normal University, China Three Gorges University, China University of Geoscience, Huazhong Agricultural University, Huazhong University of Science and Technology, Hubei University of Economics, Jianghan University, Jingchu University of Technology, South-Central University for Nationalities, Wuhan Institute of Technology, Wuhan Textile University, Wuhan University of Technology and Yangtze University). Hubei province is located in central China is one of the province that has many academic institution in China with many international students close to $21,371^{15,49}$. We selected Hubei province because it was where the Pandemic started, within its capital Wuhan. The survey data was collected through using a Microsoft online questionnaire with main reasons being the restriction of physical contacts due the impact of COVID-19 by applying social distance and easy of collection, this method has proved to be effective in many studies that are currently being conducted during this time of COVID-19 7,50.

In this study we used a method applied by Yamane $(1967: 886)^{51}$ to calculate a sample size with $95 \%$ confidence level and $P=.05{ }^{51}$. A total sample size of 392 was found using the population of 21,371 of total number of IS in Hubei Province of China. 
$x=\frac{N}{1+\mathrm{N}(e) 2}$

Where $\mathrm{N}=$ Total number of Population Where $\mathrm{n}$ is the sample size, $\mathrm{N}$ is the population size, and e is the level of precision.

This study used a non-probability sampling methods of convenience sampling technique to identified and recruit its respondents from the selected university. After calculation of sample size, a total number of 392 respondents were targeted. A single Microsoft online form with a questionnaire was sent to the randomly selected universities through their representatives into their respective WeChat groups where everyone was responding there. Out of 392 targeted respondents, a final total of 300 respondents answered the questionnaires representing $76.5 \%$ response rate. The study only included the IS who were in China during COVID-19 pandemic all those IS that were evacuated or at home because of holiday were restricted to participate through a section which was put on the questionnaire.

\subsection{Study Validation and Pilot study}

In coming up with the final instrument, this study involved three experts in the field from universities of Bangladesh, Tanzania and China who assessed the instrument and gave their advice, thereafter all necessary adjustments were done accordingly. Further we conducted a pilot study involving 30 international students including undergraduate and postgraduate from Yangtze University to assess the instruments validity and reliability. We calculated the internal reliability with Cronbach's alpha of 0.62 from the results obtained.

\subsection{Ethical consideration}

This study was conducted by following the procedures laid down by the Helsinki agreement Declaration 2008 on procedures conducting studies that involves human beings ${ }^{52}$, further, Yangtze University Internationals Student Office reviewed the ethics of the study (Approval Ref number: REF/YU/2020/07). The participation to this study was voluntarily and that all the respondents were communicated in advance with a clear written statement attached on the questionnaire that they could withdrew at any time without any problem.

\subsection{Data analysis}

Quantitative data was analysed by the software's of IMB SPSS version 24, descriptive statistics were performed to find the frequencies, means and standard deviations of the social demographic data and research variables. Correlations (Pearson was put at significant at the 0.01 level 2-tailed) to test the Hypothesis. While qualitative data was presented after critically looking at the credibility of the journals and sites retrieved.

\section{Results}




\subsection{Social demographic characteristics}

In this study a total of 300 participants participated. Table 1 shows social demographic characteristics of these participants. The results indicate that there was almost equal participation of male and female with $49 \%(\mathrm{~N}=147)$ and $51 \%(\mathrm{~N}=153)$ respectively. Most of the respondents belonged to age group of 20-30 years with total Mean and SD of $(2.01,0.375)$ respectively, about $93 \%(\mathrm{~N}=279)$ were single, of which the majority of them were doing undergraduate studies $79 \%(\mathrm{~N}=237)$. Furthermore, $51.7 \%(\mathrm{~N}=155)$ were Christians while $37 \%(N=111)$ were Muslims 5 , while $64 \%(N=192)$ of the respondents had experience of staying in China for more than 2 years.

\subsubsection{Research variables}

Table 2 Shows descriptive characteristics of research variables. While assessing their safety and security the majority of the respondents answered that they are not going to die $88.7 \%$ Mean $=1.89$ and $S D=.318$, it's like any other diseases $60.7 \%$ Mean=1.61 and SD $=.489$ and there were safe in China $88 \%$ Mean $=1.89$ and $S D=.318$. About $76.7 \%$ indicated that they received all the adequate necessary information on the timely manner from authorities with a total Mean=1.7 and $S D=.424$. Lastly, when asked about governments directive measures on social distances, the majority of the respondents thought it was necessary to use isolations for their safety and security $90.3 \%$ Mean=1.9 and $S D=2.96$, while about $92.3 \%$ Mean=1.92 and $S D=.26$ indicated that it was even necessary to follow them, and that about $60.7 \%$ Mean=1.61and $S D=.389$ indicated that it was not difficult for an individual to follows all the measures laid down.

\subsubsection{Source of information}

Table 3 Shows the results that most of the students got the information of COVD-19 from internet platforms $70.3 \%(\mathrm{~N}=211)$ seconded by school notifications $25 \%(\mathrm{~N}=75)$.

\subsubsection{Relationship between research variables}

\subsubsection{Hypothesis testing}

The aim of testing the hypothesis was to reject the false one and accept the correct one.

Table 4 shows the results of Person correction that there was a positive correlation between the variables of social distance measures implemented by the authorities and information dissemination $r=.289, P=$ .000 ( $p<0.01$ (2-tailed)) which have positive impact on safety and security perception levels, further, the results indicated that there was a positive correlation between safety and security perceptions of international students and social distance measures $r=.178, P=.002,(p<0.01$ (2-tailed)). However, the findings show that there was no significant relationship between Information dissemination and safety 
and security of IS $r=0.051, p=0.375$. Therefore, we reject the first Null hypothesis $\left(\mathrm{H}_{0}\right)$ which states that 'Government Social distances measures had a positive impact on IS safety and security perceptions' and we accept the alternative hypothesis $\left(\mathrm{H}_{1}\right)$ which says that 'Government Social distances measures had a negative impact on IS safety and security perceptions. We further accept the second Null Hypothesis $\left(\mathrm{H}_{0}\right)$ which says 'Government information dissention measures (actions) had a positive impact on IS safety and security and reject the alternative hypothesis $\left(\mathrm{H}_{1}\right)$ which states that 'Government Information dissention measures (actions) had a negative impact on IS safety and security perception'.

\section{Discussion}

This study was aimed at finding out the effects of government actions on the safety and security perceptions of the IS in China during the time COVID-19 pandemic. This study used variables of information dissemination and social distance measures enforced by the government to assess the influence the safety perceptions.

On social demographic part this study has found out that the majority of IS were young, single, doing undergraduate studies and having stayed in China for than two year which makes them having with more experience of stay, this factor of experience could be explained with the reasons that the majority of these students are doing majors that last up to 5 years, like the majors of medical and engineering that are mainly studied by the majority of international students in China ${ }^{53,54}$ which could have also contributed to have given them more experience or years of stay in China that has helped them to build trust on the authorities based on their previous experience when it comes to handles issue, as other studies found that experience with other people's helped to build trust on safety and security ${ }^{41}$.

In terms of information dissemination, this study has found out that IS benefited more from the advancement of technology just like as any other human beings are benefiting from it, where they have been able to find all adequate necessary information by using all available online social media and other platforms which are the current trend way of communications especially to the youth generation which the study has further found that the majority of respondents belong to this category. The adequate and relevance of information dissemination has also been contributed by Chinese universities as they have attributed for the frequently provision of school notifications to the students during the pandemic time, our findings of this study on high dissemination means of information agrees with other recent studies on IS in China which are said to have even go the extent of even helping in phycological perspectives to the students ${ }^{55}$. Despite having the good background of information dissemination this study has found out that the information dissemination has no correlation effect on IS perceptions on security and safety of COVID-19 pandemic, the results differ with other results where they found that information dissemination was vital to increase safety and security perception of the foreigners in general ${ }^{41}$. The explanation behind this difference may be attributed due to the nature of our study design, the respondents and other uncontrolled limitations associated to the sample and timing of the study which could have been contributing to this effect. 
On the aspect of government measures of social distancing. This study found out that the actions of the authorities that involved social distance measures like isolation, lockdowns, mandatory of wearing masks have positively influenced the safety and security perception of the international students in China. On the same point, this study has further found that almost all the students were even able to adhere to these social distance measures implemented by the authorities, these findings agrees with other studies that found out that government actions especially during in times of pandemics or any disasters would positively influence the perception of safety and security in that country 24,36 , however, this can also be argued that, on the aspect of close to $100 \%$ adherence to social distance measures by the students could be further explained with the reasons that it is because of the nature of the COVID-19 which it has showed to the world, also with the fact that the students could be persuaded to adhere due to fear of being punished and other consequences that could follow them if they did not adhere and not only is associated to their safety and security perception of COVID-19. Furthermore, the positive impacts that are attributed to social distance actions could also be traced to traced and associated with the material support, supervision and social support that the Chinese authorities provided during the Pandemic time. The findings indicate that due to the nature of the COVID-19 and measures implemented by the authorities it was reasonable for IS basic needs to be facilitated by their respective school teachers which in return reduced the risk of students contracting the virus by avoiding contacts with other people, as the Virus was a pathogens that could be transmitted from one person to another even could contaminate the air for some time ${ }^{38,56}$ and this could in turn did increase the positive perception of the safety and security among IS. On the other hand, it is clear that the lives of the international students were at the heart of high office authorities as expected from time to time to be like which is demonstrated by remarks and quick responses from the Chinese authorities. Its evidenced that the fight against COVID19 had a full political will support from the top leaders authorities in China which can be evidenced through remarks in the response of the letter from authorities to foreign students in China ${ }^{57-59}$. This is not really a surprise as it can further be explained with the fact that international students have diplomatic endeavours as such they attract top level decision and that the will of top political leaders was a good one toward the foreigners in China which is highly recommended and appreciated especially in times of pandemics like of COVID-19 20,57.

\subsection{Study limitations}

This study had some limitation just like any other study, firstly on secondary data the study relied upon information from government sources and other Scholars that could be subject to bias which could not be controlled by the researchers, however the credibility of the sources and crosschecking of the data minimised this limitation, secondly, some students did not want to respond to the questionnaire with their personal reasons which could be argued to influence biasness to the overall results of this study as they may hold some of the information that would be of helpful to this study, however this biasness was addressed by informing the responded that the survey was anonymous and it was confidential. lastly this study relied on convenience sampling techniques by collecting data from students through the identified 
leaders who could also have biases in distributing the questionnaire, however, this limitation was minimised by increasing the sample size from many universities.

\section{Conclusion}

This study focused on international students who are migrants and foreigners belonging to special minority group which need always to be protected by authorities in host countries in breach of which has a lot of diplomatic and international endeavours. With the coming of COVID-19 many students were still in China and experienced the pandemic together with their native friends, due to nature of COVID-19 it is not surprising that this study found out that information was adequate and given on a timely manner either accessed through internet or by school notifications. The social distance measured implemented by the government have proved to be effective way to contribute to the positive higher safety and security perception of the international students towards COVID-19. On their part the government tried to provide and facilitate necessary support to foreign student.

The findings of this results are very important to the international student community as they give them confidence of their safety and security and improve their decision when choosing to come and study abroad, also these results will help the policy makers as they give them a direction and a measuring stick on how to improve and continue where they did best. Lastly, we recommend future studies to be done on aspects of physiological and economic impacts of COVID-19 on international students. We further recommend the authorities all over the world as demonstrated in China to continue putting the safety and security issues of international students at their heart.

\section{Declarations}

\section{Ethics approval and consent to participate}

This study was conducted by following the procedures laid down by the Helsinki agreement Declaration 2008 on procedures conducting studies that involves human beings ${ }^{52}$, further, Yangtze University Internationals Student Office reviewed the ethics of the study (Approval Ref number: REF/YU/2020/07). The participation to this study was voluntarily and that all the respondents were communicated in advance with a clear written statement attached on the questionnaire that they could withdrew at any time without any problem

\section{Consent for publication}

Not applicable.

\section{Availability of data and materials}

All data applicable for this study is available and provided in this paper, any special request is welcome to the corresponding author. 


\section{Declaration of Competing Interest}

The authors declare t have known no any competing Interest

\section{Funding}

No funding was provided on this project

\section{CRediT authorship contribution statement}

Wu Xuelian and Shi Yu: Conceptualizing the framework, interpretation of the results and final editing; George N. Chidimbah Munthali and John Kudzala: Writing and data analysis.

\section{Acknowledgement}

We would like to thank Yangtze University Intentional Student Office and School of Economics and Management for the unwavering support they have rendered during the process of producing this paper. We also thank Dr Olutosin A. Otekunrin for the comments, Lastly, we would like to thank the all the other universities and their represenattaive who helped to faciliatate the data collection exercise; Gama Rivas, Ayivi Yao, Amponsah Randy Kwaku, Jambo Eric, Natasha Mbiza, Madina Kurmanali, Chisomo Grace Hamusuku, Nsabimana Shema Damars, Sihalath Phutthana, Prisca Raphael Kalinga, Marie Josephine Njiezu Ngounou and Mujib Wohol.

\section{References}

1. Munthali GNC, Xuelian W. COVID-19 Lockdown Measures on Least Developing Economies in Africa-a case of Malawi Economy. Tech Soc Sci J. 2020;7(Vol 7):295-301. doi:10.47577/tssj.v7i1.394

2. Amponsah R, Frimpong IA. Ghana in the Face of COVID-19: Economic Impact of Coronavirus (2019NCOV) Outbreak on Ghana. Open J Bus Manag. 2020;08(04):1404-1411. doi:10.4236/ojbm.2020.84089

3. Xuelian W. The Future of Tobacco Industry Amidst of COVID-19 -A Case of Malawi Producing Country. Biomed J Sci Tech Res. 2020;27(5):21104-21109. doi:10.26717/BJSTR.2020.27.004566

4. Rahman A, Sathi NJ. Knowledge, Attitude, and Preventive Practices toward COVID-19 among Bangladeshi Internet Users. Electron J Gen Med. 2020;17(5):em245. doi:10.29333/ejgm/8223

5. D NPS, Namakhwa D, George N, Munthali C, Chirambo AM. Current advancements on Covid-19 potential treatments: Learning from literature review. Int J App/ Chem Biol. 2021;(January).

6. Otekunrin OA, Otekunrin OA, Fasina FO, Omotayo AO. Assessing the Zero Hunger Target Readiness in Africa in the Face of COVID-19 Pandemic. 2020;(October). doi:10.20961/carakatani.v35i2.41503

7. Mogaji E. Impact of COVID-19 on transportation in Lagos, Nigeria. Transp Res Interdiscip Perspect. 2020;6(June):100154. doi:10.1016/j.trip.2020.100154 
8. Onyema EM, Sen S, Alsayed AO. Impact of Coronavirus Pandemic on Education. J Educ Pract. 2020; (June). doi:10.7176/JEP/11-13-12

9. Iyer P, Aziz K, Ojcius DM. Impact of COVID-19 on dental education in the United States. J Dent Educ. 2020;84(6):718-722. doi:10.1002/jdd.12163

10. Gupta A, Goplani MM. Purakala ( UGC Care Journal ) IMPACT OF COVID-19 ON EDUCATIONAL IMPACT OF COVID-19 ON EDUCATIONAL INSTITUTIONS IN INDIA. 2020;(May).

11. Dawadi S, Simkhada P. Impact of COVID-19 on the Education Sector in Nepal - Challenges and Coping Strategies. Sage Submissions. 2020;3(May):16. doi:10.31124/advance.12344336.v1

12. OECD. Education at a Glance 2019 (Summary in Spanish). In: OECD-Edcation at Glance. ; 2019. doi:10.1787/f6dc8198-es

13. Training A-D of E and. China - Outbound and Inbound International Students.; 2016.

14. UNESCO. International (or internationally mobile) students I UNESCO UIS. UNESCO UIS. http://uis.unesco.org/en/glossary-term/international-or-internationally-mobile-students. Published 2020. Accessed August 5, 2020.

15. Moe.gov.cn. Statistical report on international students in China for 2018 - Ministry of Education of the People's Republic of China. moe.gov.cn.

http://en.moe.gov.cn/documents/reports/201904/t20190418_378692.html. Published 2020. Accessed May 11, 2020.

16. Growing number of foreign students choosing to study in China for a degree across multiple disciplines - Ministry of Education of the People's Republic of China. http://en.moe.gov.cn/News/Top_News/201804/t20180403_332258.html. Accessed August 6, 2020.

17. Wei G, Lin W, Jingdong Y, Yanxiong W. China as a Global Destination for International Students. J Polit Law. 2020;13(1):135. doi:10.5539/jpl.v13n1p135

18. Latief R, Lefen L. Analysis of Chinese Government Scholarship for International Students Using Analytical Hierarchy Process (AHP). Sustainability. 2018;10(7):2112. doi:10.3390/su10072112

19. Lu H, Rohr C, Hafner M, Knack A. China Belt and Road Initiative: Measuring the Impact of Improving Transportation Connectivity on Trade in the Region. RAND Corporation; 2018. doi:10.7249/RR2625

20. Wen W. Inbound international student policies in China: a historical perspective. Asian Educ Dev Stud. 2018;7(2):174-183. doi:10.1108/AEDS-09-2017-0097

21. Babones S. The China Student Boom and the Risks It Poses to Australian Universities. 2019; (August).

22. Austin L, Shen L. Factors influencing chinese students' decisions to study in the United States. J Int Students. 2016;6(3):722-732.

23. Hasan MK, Younos TB. Safety culture among Bangladeshi university students: A cross-sectional survey. Saf Sci. 2020;131(April):104922. doi:10.1016/j.ssci.2020.104922

24. Lee JJ, Sehoole C. International Students Seeking Political Stability and Safety in South Africa. High Educ Policy. 2020;33(2):305-322. doi:10.1057/s41307-019-00171-z 
25. Bodomo A. Africa-China-Europe relations: Conditions and conditionalities. J Int Stud. 2019;12(4):115129. doi:10.14254/2071-8330.2019/12-4/8

26. Rodan P. The International Student as Student, Migrant and Victim: Changing Perceptions in a Vexed Area of Public Policy. Aust Univ Rev. 2009;51(2):27-31.

27. Insch A, Sun B. University students' needs and satisfaction with their host city. J Place Manag Dev. 2013;6(3):178-191. doi:10.1108/JPMD-03-2013-0004

28. Mazzarol T, Soutar GN. "Push-pull" factors influencing international student destination choice. Int $J$ Educ Manag. 2002;16(2):82-90. doi:10.1108/09513540210418403

29. Nyland $\mathrm{C}$, Forbes-Mewett $\mathrm{H}$, Marginson $\mathrm{S}$. The international student safety debate: moving beyond denial. High Educ Res Dev. 2010;29(1):89-101. doi:10.1080/07294360903277364

30. Potter R, Lee JJ. S. Marginson, C. Nyland, E. Sawir, and H. Forbes-Mewett: International student security. High Educ. 2012;64(1):135-137. doi:10.1007/s10734-011-9469-0

31. Ma T, Heywood A, MacIntyre CR. Travel health risk perceptions of Chinese international students in Australia - Implications for COVID-19. Infect Dis Heal. 2020;25(3):197-204.

doi:10.1016/j.idh.2020.03.002

32. Fakhar-e-Alam Kulyar M, Bhutta ZA, Shabbir S, Akhtar M. Psychosocial impact of COVID-19 outbreak on international students living in Hubei province, China. Travel Med Infect Dis. 2020;(April):101712. doi:10.1016/j.tmaid.2020.101712

33. Kohn NA, Kohnt NA, Abrams J, et al. Vulnerability Theory and the Role of Government Recommended Citation Vulnerability Theory and the Role of Government. Yale J Law Fem Artic. 2014;26(1).

34. Yun I, Kercher G, Swindell S. Fear of Crime Among Chinese Immigrants. J Ethn Crim Justice. 2010;8(2):71-90. doi:10.1080/15377931003760989

35. Barberet R, Fisher BS, Taylor H. University Student Safety In The East Midlands.; 2004. doi:10.1037/e635352007-001

36. Misago JP, Freemantle I, Landau LB. Protection from Xenophobia: An Evaluation of UNHCR's Regional Office for Southern Africa's Xenophobia Related Programmes.; 2015.

37. Ilieva J. Do political events in host countries affect international education engagement? In: ; 2017.

38. World Health Organization (WHO). Novel Coronavirus (2019-NCoV) Situation Report - 121 January 2020.; 2020.

39. Nas S. The Definitions of Safety and Security. J ETA Marit Sci. 2015;3(2):53-54. doi:10.5505/jems.2015.42713

40. Li M. Keeping them safe: A review of Chinese students' safety issues in New Zealand. In: Keeping Them Safe: A Review of Chinese Students' Safety Issues in New Zealand. ; 2008:1-30.

41. Song G, Liu L, He S, Cai L, Xu C. Safety perceptions among African migrants in Guangzhou and Foshan, China. Cities. 2020;99(February):102624. doi:10.1016/j.cities.2020.102624

42. BOX S, HALE C, ANDREWS G. EXPLAINING FEAR OF CRIME. Br J Criminol. 1988;28(3):340-356. doi:10.1093/oxfordjournals.bjc.a047733 
43. Shao P. Impact of city and residential unit lockdowns on prevention and control of COVID-19. medRxiv. 2020;21(1):1-9. doi:https://doi.org/10.1101/2020.03.13.20035253

44. Jamison DT, Summers LH, Alleyne G, et al. A World Converging within a Generation Policy Brief \# 2: The Returns to Investing in Health. Geneva World Heal Organ. 1993;I(1):2-3. doi:10.1073/pnas.1400475111

45. Arenas A, Cota W, Gomez-Gardenes J, et al. A mathematical model for the spatiotemporal epidemic spreading of COVID19. medRxiv. 2020:2020.03.21.20040022. doi:10.1101/2020.03.21.20040022

46. Wu Y, Wen J. Fear of crime among Chinese immigrants in Metro-Detroit. Crime, Law Soc Chang. 2014;61(5):495-515. doi:10.1007/s10611-014-9513-y

47. LEE MS, ULMER JT. FEAR OF CRIME AMONG KOREAN AMERICANS IN CHICAGO COMMUNITIES. Criminology. 2000;38(4):1173-1206. doi:10.1111/j.1745-9125.2000.tb01418.x

48. Poudel-Tandukar K, Nakahara S, Ichikawa M, Poudel KC, Jimba M. Risk perception, road behavior, and pedestrian injury among adolescent students in Kathmandu, Nepal. Inj Prev. 2007;13(4):258263. doi:10.1136/ip.2006.014662

49. Bovenkamp J van de and YF. Economic Overview of Hubei Province Economic Overview of. 2016:119.

50. Gong Y. Safety culture among Chinese undergraduates: A survey at a university. Saf Sci. 2019;111(September 2018):17-21. doi:10.1016/j.ssci.2018.09.010

51. Israel GD. Using Published Tables Using Formulas To Calculate A Sample Size Using A Census For Small Populations.

52. Kong H, West S, States U. World Medical Association Declaration of Helsinki: ethical principles for medical research involving human subjects. J Am Coll Dent. 2014;81(3):14-18. doi:10.1093/acprof:oso/9780199241323.003.0025

53. Obed L, Banda L, Liu J, Banda JT. TRENDING MAJORS AMONG INTERNATIONAL STUDENTS IN CHINA: A CASE OF AFRICAN STUDENTS? Graduate School of Education , Beijing Institute of Technology . No . 5 South. 2020;(November). doi:10.6084/m9.figshare.13269533

54. Diane Mukundwa;Amida Nyiranyamibwa;Albert Kasonde;Everjoy Tatenda Shumba;Prisca Raphael Kalinga;Mercia Tapfuma;Rita Jeremiah Mollel;Misheck Kaluba;Rita Umuhire;Claudette Sangwa;Bwalya Malama;George N. Chidimbah Munthali; Wu Xuelian. COVID-19 MEDICAL STUDENT PERSPECTIVE-OUR EXPERIENCE. Eur J Pharm Med Res. 2021;8(1):69-71.

55. Chen W. International Students' Coping Strategies and Psychological Adaption during Early the COVID-19 Outbreak Period in China. Open J Soc Sci. 2020;08(08):29-40. doi:10.4236/jss.2020.88003

56. Munthali GNC, Xuelian W. Covid-19 Outbreak on Malawi Perspective. Electron J Gen Med. 2020;17(4):em210. doi:10.29333/ejgm/7871

57. CGTN. Xi replies to letter from Pakistani students studying in Beijing - CGTN. CGTN. https://news.cgtn.com/news/2020-05-18/Xi-replies-to-letter-from-Pakistani-students-studying-inBeijing-QAvThGhShi/index.html. Published 2020. Accessed August 23, 2020. 
58. China.org.cn. Xi replies to letter from Pakistani students studying in Beijing- China.org.cn.

China.org.cn. http://www.china.org.cn/china/2020-05/18/content_76058407.htm. Published 2020. Accessed August 23, 2020.

59. GeoNews. China welcomes outstanding people from across the world: President Xi responds to Pakistani students. GeoNews. https://www.geo.tv/latest/288508-china-welcomes-outstandingpeople-from-across-the-world-president-xi-responds-to-pakistani-students. Published 2020. Accessed August 23, 2020.

\section{Tables}

Table 1: Social demographic characteristics $(\mathrm{N}=300)$

\begin{tabular}{|c|c|c|c|c|c|}
\hline Variables & & Frequency & Percent (\%) & Mean & SD \\
\hline \multirow[t]{2}{*}{ Gender } & Male & 147 & 49 & & \\
\hline & Female & 153 & $51^{*}$ & 1.51 & 0.501 \\
\hline \multirow[t]{3}{*}{ Age Group } & $<20$ & 19 & 6.3 & & \\
\hline & $20-30$ & 258 & $86^{*}$ & & \\
\hline & $30+$ & 23 & 7.7 & 2.01 & 0.375 \\
\hline \multirow[t]{3}{*}{ Marital Status } & Single & 279 & $93^{*}$ & & \\
\hline & Married & 12 & 4 & & \\
\hline & Others & 9 & 3 & 1.13 & 0.542 \\
\hline \multirow[t]{2}{*}{ Level of Program } & Undergraduate & 237 & $79 *$ & & \\
\hline & Postgraduate & 63 & 21 & 1.21 & 0.408 \\
\hline \multirow[t]{3}{*}{ Experience } & $<1$ & 57 & 19 & & \\
\hline & $1-2$ & $1-2$ & 17 & & \\
\hline & $2+$ & 192 & $64 *$ & 2.45 & 0.793 \\
\hline \multirow[t]{6}{*}{ Religion Affiliation } & Islam & 111 & 37 & & \\
\hline & Christian & 155 & $51.7 *$ & & \\
\hline & Buddhist & 6 & 2 & & \\
\hline & Hinduism & 4 & 4 & & \\
\hline & Don't want to disclose & 19 & 6.3 & & \\
\hline & Others & 5 & 1.7 & 1.93 & 1.131 \\
\hline
\end{tabular}


Note: * Frequency above $50 \%$

Table 2: Frequencies of research variables

\begin{tabular}{|c|c|c|c|c|c|c|}
\hline \multirow[t]{2}{*}{ Variables Statement } & \multicolumn{2}{|l|}{ Yes } & \multicolumn{2}{|l|}{ No } & \multirow[t]{2}{*}{ Mean } & \multirow[t]{2}{*}{ SD } \\
\hline & $\boldsymbol{F}$ & $\%$ & $\boldsymbol{F}$ & $\%$ & & \\
\hline \multicolumn{7}{|l|}{ a. Safety and Security } \\
\hline $\begin{array}{l}\text { 1. How was your reaction after hearing the COVID- } \\
19-\text { I am going to Die? }\end{array}$ & 34 & 11.3 & 266 & 88.7 & 1.89 & 0.318 \\
\hline $\begin{array}{l}\text { 2. How was your reaction after hearing the COVID- } \\
19 \text { - It is like any other disease I will be okay? }\end{array}$ & 182 & $60.7^{\star}$ & 188 & 39.3 & 1.61 & 0.489 \\
\hline 3. Do you still feel safe in China after the Outbreak? & 264 & $88^{*}$ & 36 & 12 & 1.88 & 0.326 \\
\hline \multicolumn{7}{|l|}{ b. Information Dissemination } \\
\hline $\begin{array}{l}\text { 4. All the adequate information regarding COVID-19 } \\
\text { was provided to me by those in authorities on a } \\
\text { timely manner? }\end{array}$ & 230 & $76.7 *$ & 70 & 23.3 & 1.77 & 0.424 \\
\hline \multicolumn{7}{|l|}{ c. Social Distance Measures } \\
\hline $\begin{array}{l}\text { 5. It was necessary for those with COVID- } 19 \text { to be } \\
\text { kept on isolation as one way of social distance } \\
\text { measures? }\end{array}$ & 271 & $90.3^{*}$ & 29 & 9.7 & 1.9 & 0.296 \\
\hline $\begin{array}{l}\text { 6. It was necessary to follow all the preventative } \\
\text { measures like wearing Masks, etc? }\end{array}$ & 277 & $92.3^{*}$ & 23 & 7.7 & 1.92 & 0.267 \\
\hline $\begin{array}{l}\text { 7. It is difficult for an individual to follow all the } \\
\text { social distance measures laid down by the } \\
\text { authorities? }\end{array}$ & 118 & 39.3 & 182 & 60.7 & 1.61 & 0.389 \\
\hline
\end{tabular}

Note: * Frequency at above 50\%, SD=Standard Deviation

Table 3: Source of information $(\mathrm{N}=300)$ 


\begin{tabular}{|cllc|}
\hline Source of Information & Frequency & \multicolumn{1}{c|}{ Percent (\%) } \\
\hline Internet Platforms & 211 & $70.3^{*}$ \\
\hline School Notification & 75 & $25.0^{\star}$ \\
\hline Wires, TV and Radio & 7 & 2.3 \\
\hline Family and Friends & 3 & 1.0 \\
\hline Others Means & 4 & 1.3 \\
\hline
\end{tabular}

Note: *frequency at $25 \%$ above

Table 4: Relationships between variables

\begin{tabular}{|lllll|}
\hline Variables & & $\mathbf{1}$ & $\mathbf{2}$ & $\mathbf{3}$ \\
\hline 1.Safety and Security & Pearson Correlation & 1 & & \\
& Sig. (2-tailed) & & & \\
& N & 300 & & \\
\hline 2.Information Dissemination & Pearson Correlation & .051 & 1 & \\
& Sig. (2-tailed) & .375 & & \\
\hline & N & 300 & 300 & \\
\hline 3.Social Distance Measures & Pearson Correlation & $.178 *$ & $.289 *$ & 1 \\
\hline & Sig. (2-tailed) & .002 & .000 & \\
\hline & N & 300 & 300 & 300 \\
\hline
\end{tabular}

${ }^{* *}$ Correlation is significant at the 0.01 level (2-tailed)

Source: author computed data

Figures 


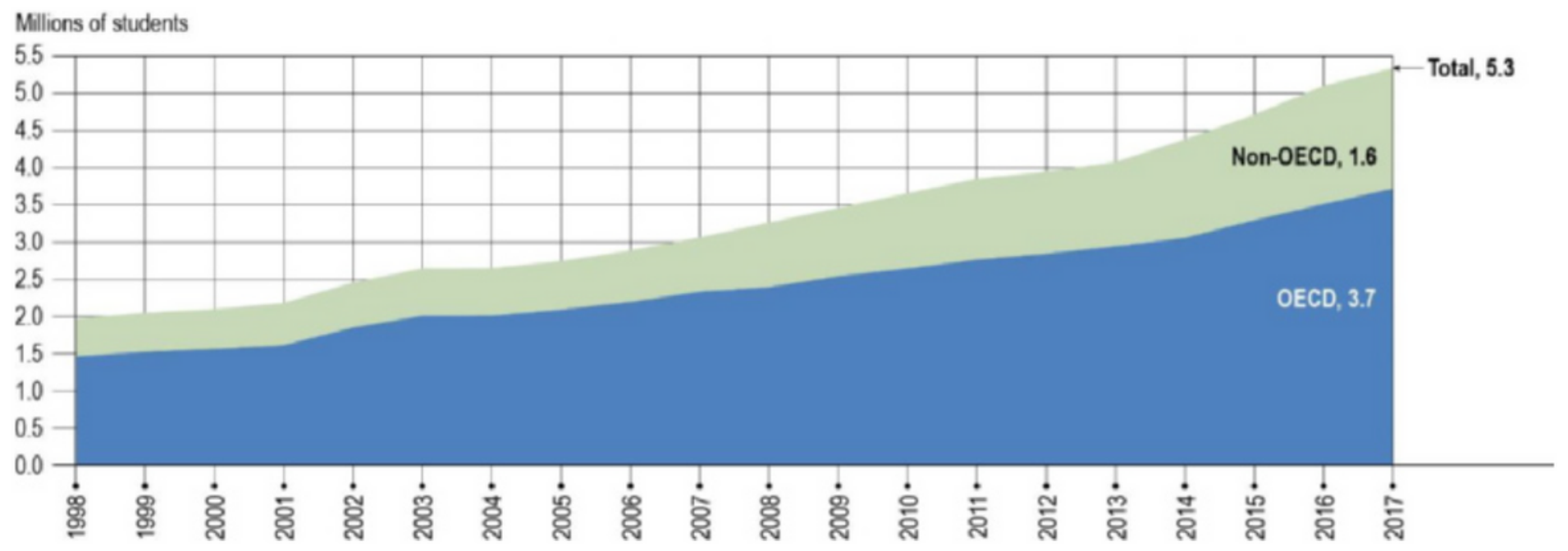

Figure 1

Show number of international students enrolled in OECD and non-OECD countries Source: OECDEducation at Glance (2019)12.

\section{Do you still feel safe in China after the Outbreak?}

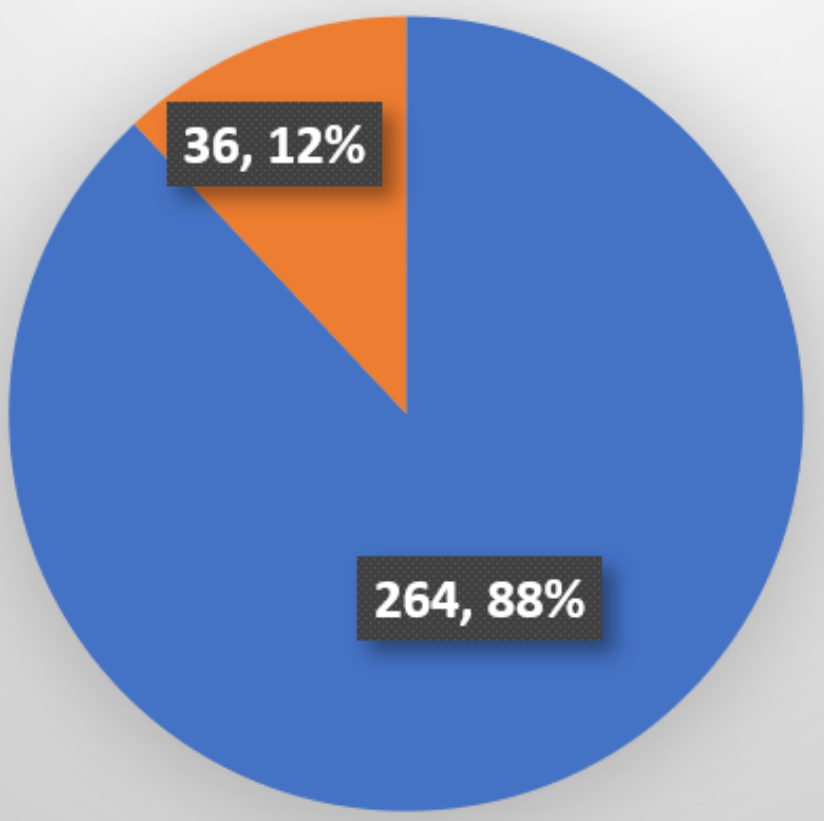

\section{Figure 2}

Showing a Pie Chart indicating the percentage of safety in China 